\title{
Optimization and characterization of enterocin Enterococcus faecalis K2B1 isolated from Toraja's Belang Buffalo Milk, South Sulawesi, Indonesia
}

\author{
HASRIA ALANG ${ }^{1, \bullet}$, JONI KUSNADI ${ }^{2}$, TRI ARDYATI ${ }^{3}$, SUHARJONO ${ }^{3}$ \\ ${ }^{1}$ Department of Biology, STKIP-PI Makassar. Jl. Inspeksi Kanal Citraland No. 10, Aroepala, Gowa 92113, South Sulawesi, Indonesia. \\ Tel.: +62-829-0364-760, ‘email: hasriaalangbio@gmail.com \\ ${ }^{2}$ Department of Agriculture Technology, Faculty of Agriculture Technology, Universitas Brawijaya. Jl. Veteran, Malang 65145, East Java, Indonesia \\ ${ }^{3}$ Department of Biology, Faculty of Mathematics and Natural Sciences, Universitas Brawijaya. Jl. Veteran, Malang 65145, East Java, Indonesia
}

Manuscript received: 9 December 2019. Revision accepted: 25 February 2020.

\begin{abstract}
Alang H, Kusnadi J, Ardyati T, Suharjono. 2020. Optimization and characterization of enterocin Enterococcus faecalis K2B1 isolated from Toraja's Belang Buffalo Milk, South Sulawesi, Indonesia. Biodiversitas 21: 1236-1242. The growing bacterial resistance needs to be controlled with effective antimicrobials. Bacteriocins are proteinaceous toxins produced by bacteria to inhibit the growth of pathogens. Bacteriocin industry has substantially grown, replacing the role of chemical preservatives in enhancing shelf-life and food safety. Bacteriocin produced by genera Enterococcus can be used as an antimicrobial against pathogen. In this study, we used Enterococcus faecalis K2B1 which was first isolated from Toraja's Belang Buffalo Milk Makassar, Indonesia. The study aimed to optimization and characterization of Enterocin produced by Enterococcus faecalis K2B1, isolated from Toraja's Belang buffalo milk. Research Method: including optimization and characterization of antimicrobial metabolite (BLIS) using MRS broth with different initial $\mathrm{pH}$ (pH 6, 7 and 8), and partial purification with ammonium sulfate on different concentration (40,60 and $80 \%$ ). Result showed that BLIS production was most optimal on MRS broth at initial $\mathrm{pH}$ of 8 after $13^{\text {th }}$ hour fermentation, at late exponential phase. BLIS characterization visibly active at high temperatures and very wide range of $\mathrm{pH}$, and disappeared after treating with proteinase-K. Crude had a broad spectrum, was sensitive to Proteinase-K and estimated to have molecular weight of $5 \mathrm{kDa}$.
\end{abstract}

Keywords: BLIS, characterization, enterocin, Enterococcus faecalis, purification

Abbreviations: BLIS: Bacteriocin-Like Inhibitory Substratance, CFSN: Cell-Free Substance Neutral, MWCO: Molecular Weight CutOff

\section{INTRODUCTION}

Enterococcus is a group of Lactic Acid Bacteria (LAB), a commensal organism in the human digestive tract which can cause urinary tract infections, but generally occurs only in an immune-compromised case or as an opportunistic case (Araujo and Ferreira 2013). This bacterium can be found in various sources such as meat, milk, cheese, and fermented products (Banwo et al. 2012). Enterococcus, like other LAB groups, can produce a bacteriocin called enterocin. Bacteriocin is an antimicrobial peptide which synthesized in the ribosome. Bacteriocins play an important role in inhibiting some pathogenic bacteria to control various infections, and also can be used as bio preservatives to replace the chemical ones to control foodborne pathogens (Arquest et al. 2015; Ogaki et al. 2016; Sidek et al. 2018; Tankoano et al. 2019).

Optimum conditions for producing bacteriocin are influenced by various factors, including sources of nutrition and physical factors, such as the growth phase and initial $\mathrm{pH}$ of the media and other environmental factors (Sidek et al. 2018; Tankoano et al. 2019). Bacteriocin can be produced in a liquid substrate, and MRS broth often found to be the most prominent for growth of LAB and bacteriocin production. Bacteriocin generally produced at logarithmic phase until the stationary phase (Avaiyarasi et al. 2016; Yi et al. 2016; Bello et al. 2018; Sidek et al. 2018; Tankoano et al. 2019). However, each BAL has a different growth rate, and also requires different initial medium $\mathrm{pH}$ for its growth (Yusuf and Hamid 2012).

Enterococcus faecalis $\mathrm{K} 2 \mathrm{~B} 1$, which was indigenous LAB from Belang buffalo milk of Toraja, Indonesia, potential as a probiotic candidate were examined by Alang et al. (2019). This bacterium produces Enterocin which is able to inhibit the growth of pathogens and can be used as a bio preservative in the future. However, the optimum conditions of production and the characteristics of the bacteriocin are not yet known. This is the first study about optimization and characterization of Enterocin E. faecalis K2B1, isolated from Toraja's Belang Buffalo Milk Makassar, Indonesia. The aim of the research was for optimization and characterization of enterocin produced by that bacterium. 


\section{MATERIALS AND METHODS}

\section{Bacterial cultures}

Enterococcus faecalis K2B1 were isolated from Toraja's Belang buffalo milk, South Sulawesi, Indonesia. The indicator bacteria used in this study were Staphylococcus aureus, Pseudomonas aeruginosa and Bacillus cereus obtained from the Microbiology Laboratory, Department of Biology, Universitas Brawijaya, Malang, Indonesia. The enterocin-producing bacteria were grown in de Man Rogosa Sharpe (MRS) agar medium (Merck, Darmstadt, Germany) while the pathogenic bacteria were grown in nutrient agar (NA) medium (Merck, Darmstadt, Germany).

\section{Optimization production of enterocin Enterococcus faecalis K2B1}

Optimization of Bacteriocin-Like Inhibitory Substratance (BLIS) or Cell-Free Substance Neutral (CFSN) production was conducted multi-steps based on Yusuf and Hamid (2012), Goh and Phlip (2015), Bello et al. (2018), Sidek et al. (2018). Bacteriocin optimization was carried out using 2 important variables: initial media $\mathrm{pH}$ and incubation period. The MRS broth was adjusted to the initial $\mathrm{pH}$ of 6 , 7 and 8 using $\mathrm{NaOH}$. After that, it was incubated in a shaker for 20 hours at $37{ }^{\circ} \mathrm{C}$, with $150 \mathrm{rpm}$ agitation. Sampling was carried out starting from the logarithmic growth phase until the stationary phase $(7,9,11,13,15$, 17 , and 19 hours). Then the absorbance was recorded at $600 \mathrm{~nm}$ wavelength. The supernatant then centrifuged for $10000 \mathrm{~g}$ for 20 minutes, at $4{ }^{\circ} \mathrm{C}$. Then filtered using millipore $0,22 \mu \mathrm{m}$, and neutralized its $\mathrm{pH}$ to 6-6.5 using $\mathrm{NaOH}$. Crude was then used to observe the bacteriocin production qualitatively, which expressed in arbitrary unit (AU/mL) against $\mathrm{S}$. aureus according to the following equation (1) (Thirumurugan et al. 2015; Avaiyarasi et al. 2016).

$$
\begin{aligned}
& \mathrm{AU}=\mathrm{Lz}-\mathrm{Ls} / \mathrm{V} \ldots \ldots \ldots \ldots \ldots \\
& \mathrm{Lz}=\text { Zone width }(\mathrm{mm}) \\
& \mathrm{Ls}=\text { Well width }(\mathrm{mm}) \\
& \mathrm{V}=\text { Sample volume }(\mathrm{mL})
\end{aligned}
$$

\section{Characterization of BLIS enterocin from $\boldsymbol{E}$. faecalis K2B1}

Initial characterization of Bacteriocin Like Inhibitory Substrates (BLIS), such as sensitivity to Proteinase-K, temperature and wide range of $\mathrm{pH}$, was performed according to Sarra et al. (2013), Leite et al. (2016), Bello et al. (2018), Sidek et al. (2018). Characterization against proteinase $\mathrm{K}$ was carried out by adding the Pro-K enzyme to the supernatant, final concentration was $1 \mathrm{mg} / \mathrm{mL}$. Afterward, incubated for 1 hour at $37^{\circ} \mathrm{C}$. Characterization against the temperature was conducted using heat treatment to the supernatant, at $60^{\circ} \mathrm{C}$ for 30 minutes, $100{ }^{\circ} \mathrm{C}$ and $121^{\circ} \mathrm{C}$ for 15 minutes. $\mathrm{pH}$ characterization was carried out using the supernatant $\mathrm{pH} 6,5$, incubated for 1 hour at $37^{\circ} \mathrm{C}$, and after that adjusting $\mathrm{pH}$ to $2,3,4,8,9$ and 10. Subsequently, an antimicrobial activity test was performed using a disk diffusion assay. $100 \mathrm{uL} \mathrm{S.} \mathrm{aureus} \mathrm{with} \mathrm{a}$ density of $10^{6}$ cells $/ \mathrm{mL}$, was spread out on the surface of Petri dishes containing NA soft (1.5\%). Furthermore, it was incubated for 1 hour at $4^{\circ} \mathrm{C}$, to restrain the growth of the pathogen. Then a disk contained $50 \mathrm{uL}$ crude was placed. Disk without BLIS as a control. Then it was incubated at $37^{\circ} \mathrm{C}$ for 24 hours to observe the inhibitory zone formed.

\section{Enterocin partial purification}

E. faecalis $\mathrm{K} 2 \mathrm{~B} 1$ was grown on MRS broth medium at $37^{\circ} \mathrm{C}$ for 24 hours. Afterward, as much as $1 \%(\mathrm{v} / \mathrm{v})$ culture was transferred to 1.5 Liter MRS broth $\mathrm{pH} 8$, and incubated for 13 hours (according to the optimum phase), centrifuged $10000 \mathrm{~g}$ for 20 minutes at $4^{\circ} \mathrm{C}$ to remove cells. The supernatant $\mathrm{pH}$ then neutralized to 6.2 using $\mathrm{NaOH}$, filtered using millipore $0.22 \mathrm{um}$. Furthermore, ammonium sulfate with different concentrations $(40 \%, 60 \%, 80 \%)$ were stirred overnight at $4^{\circ} \mathrm{C}$, then centrifuged $10000 \mathrm{~g}$, for 20 minutes at $4^{\circ} \mathrm{C}$. The precipitates were resuspended 1: 1

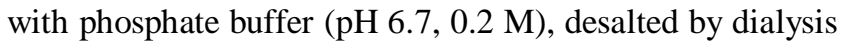
( $5 \mathrm{kDa}$ molecular weight cut off dialysis membrane pore) in phosphate buffer of $0.05 \mathrm{M}$, stirrer overnight at $4^{\circ} \mathrm{C}$. The $0,05 \mathrm{M}$ of phosphate buffer was changed four times during the incubation period. Protein concentration partially purified bacteriocin (crude) was measured based on the Bradford method, absorbance $595 \mathrm{~nm}$. Antibacterial activity BLIS, precipitated and crude also evaluated using the disc diffusion method. Total of $50 \mu \mathrm{L}$ of each sample (CFS, precipitated, and crude enterocin) was added into a blank disc $(6 \mathrm{~mm})$. The discs were spotted on NA medium that has been inoculated with $100 \mu \mathrm{L}$ of indicator bacteria (S. aureus, B. cereus, and P. Aeruginosa, $10^{6}$ cell $/ \mathrm{mL}$ ), then incubated at $37^{\circ} \mathrm{C}$ for $24 \mathrm{~h}$ and the inhibition zones were measured (Abanoz and Kunduhoglu 2018)

\section{Characterization of crude enterocin}

Characterization of crude enterocin was confirmed with proteinase $\mathrm{K}$ and estimated molecular weight (MW). The proteinaceous nature of enterocin was confirmed by treating it with proteinase $\mathrm{K}(1 \mathrm{mg} / \mathrm{mL})$ and then the antagonistic activity was tested using the disc diffusion method. The bacteriocin activities were measured based on the inhibition zones. All the experiments were conducted in triplicate. Ampicillin was used as a control in this research.

The molecular weight (MW) of crude enterocin was estimated by using the sodium dodecyl sulfatepolyacrylamide gel electrophoresis (SDS-PAGE) method (4\% stacking gel and $16.5 \%$ separating gel). A low molecular weight marker with sizes ranging from 2.5 to $45.0 \mathrm{kDa}$ was used. The electrophoresis was run using Mini-PROTEAN Tetra Cell (Bio-Rad Laboratories, Inc, Berkeley, California) for $2 \mathrm{~h}$ at $100 \mathrm{~V}$. The gel was divided into two parts, one half stained with Coomassie Blue R250. The other piece of the gel was not stained and used for a direct antimicrobial activity assay (overlay method). To remove SDS from the second lane, the SDS-PAGE gels washed and soaked in two sterile $\mathrm{dH} 2 \mathrm{O}$ changes for 60 min. The gel was transferred into a petri dish, and then overlaid with $15 \mathrm{~mL}$ of soft nutrient agar (seeded with indicator test strain at $10^{6} \mathrm{CFU} / \mathrm{mL}$ ). After incubation at $37^{\circ} \mathrm{C}$ for $24 \mathrm{~h}$, the gel was examined for the presence of an 
inhibitory zone (Goh and Philip 2015; Braiek et al. 2017; Abanoz and Kunduhoglu 2018; Bello et al. 2018; Sidek et al. 2018).

\section{Data analysis}

Data of Characterization of BLIS Enterocin from $E$. faecalis K2B1, and antimicrobial activity of crude enterocin were analyzed by ANOVA with $\alpha=5 \%$ using the SPSS 16.0 program

\section{RESULTS AND DISCUSSION}

\section{Optimization of Metabolite Production}

Enterocin production is strongly influenced by the growth phase and initial $\mathrm{pH}$ of growth media. In this study, the bacteriocin optimization began with creating a standard curve and growth curve. Incubation was carried out using MRS broth $\mathrm{pH} 5,7$ at $37{ }^{\circ} \mathrm{C}$ using a 150rpm incubator shaker. The incubation process was carried out for 24 hours. OD and $\mathrm{pH}$ values were calculated at 2-hour intervals. The exponential phase of E. faecalis K2B1, began at the $3^{\text {rd }}$ hour until the $17^{\text {th }}$ hour after fermentation (figure 1).

The optimization of bacteriocin production in this study, was carried out on MRS broth medium with different $\mathrm{pH}$ range ( $\mathrm{pH} 6,7$ and 8), and then tested for antimicrobial activity against $S$. aureus. The results showed that on MRS broth media at $\mathrm{pH} 6$, no clear zone was seen which meant that there was no bacteriocin production. Whereas at MRS broth at $\mathrm{pH} 7$, bacteriocin production was formed at the $17^{\text {th }}$ and $18^{\text {th }}$ hours of growth with arbitrary units of $48 \mathrm{~mm} 2 / \mathrm{ml}$ and $62 \mathrm{~mm} 2 / \mathrm{mL}$ respectively. On MRS broth $\mathrm{pH} 8$, the bacteriocin produced began at 9th, $11^{\text {th }}, 13^{\text {th }}$ and $15^{\text {th }}$ hours after fermentation with arbitrary unit values of $34 \mathrm{~mm} \mathrm{2/mL,} 46 \mathrm{~mm} \mathrm{2/mL,} 97.21 \mathrm{~mm} 2 / \mathrm{mL}$ and $79,56 \mathrm{~mm} 2 / \mathrm{mL}$ respectively. This indicated that the most optimum bacteriocin was produced at MRS broth initial $\mathrm{pH} 8,13^{\text {th }}$ hour after fermentation, at the end of the exponential phase (Figure 2).

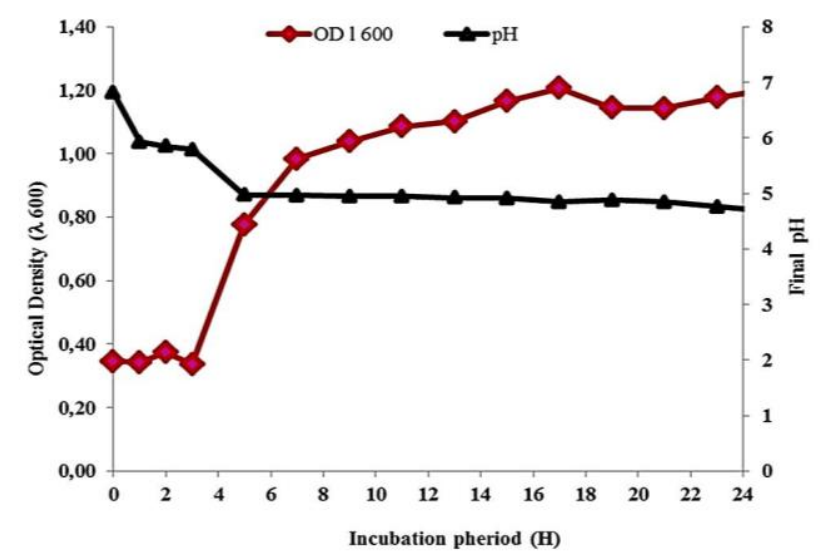

Figure 1. Growth curve of E. faecalis BLIS Characterization of E. faecalis $\mathrm{K} 2 \mathrm{~B} 1$

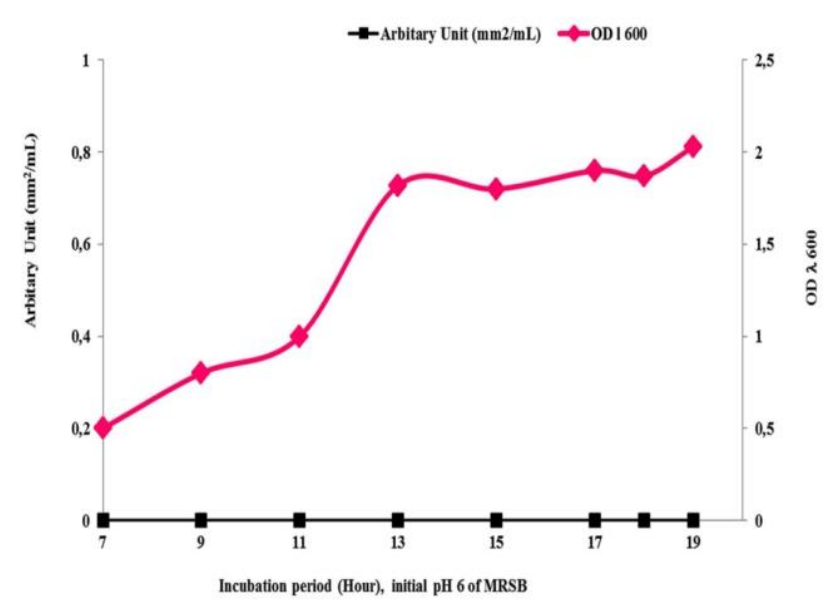

A

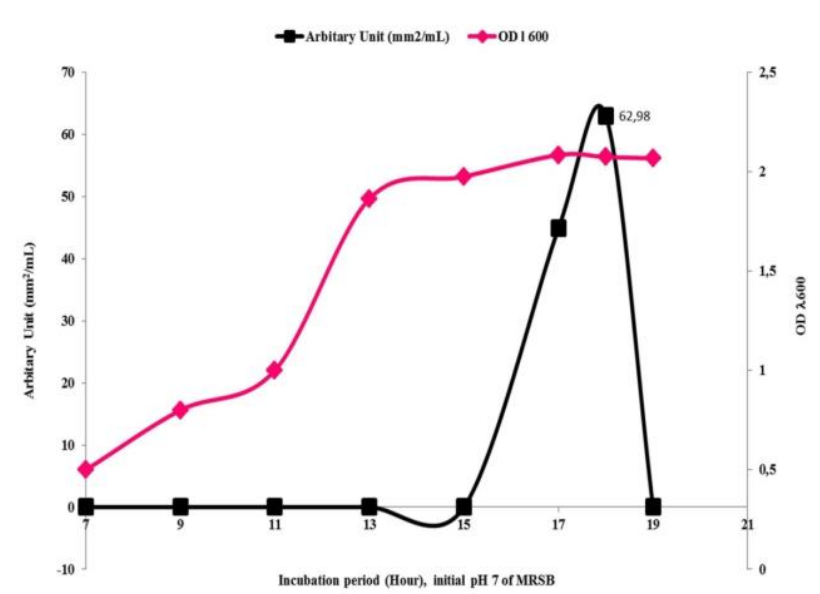

B

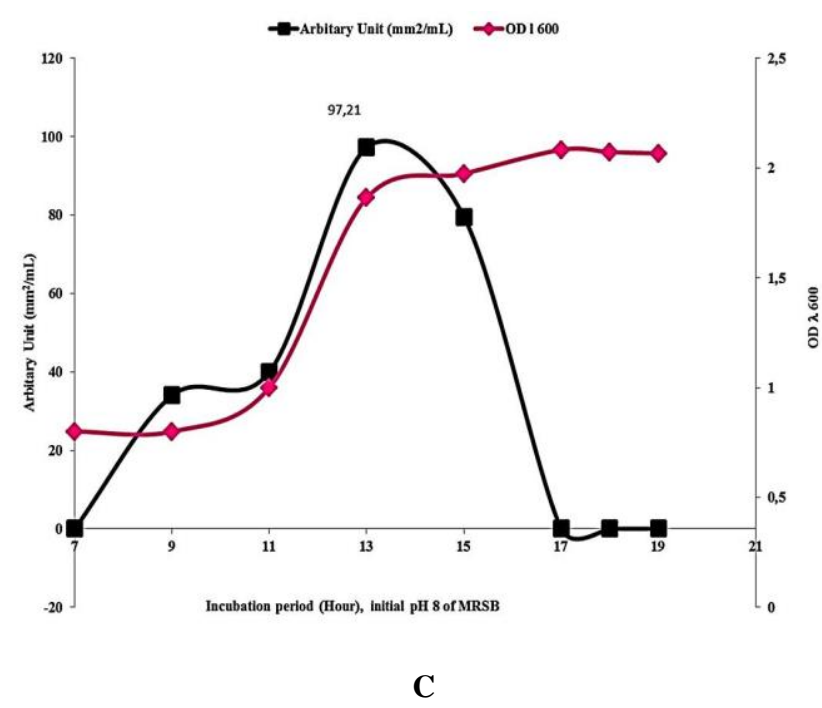

Figure 2. Effect of incubation time and initial pH. A. $\mathrm{pH}$ 6, B. $\mathrm{pH}$ 7, C. $\mathrm{pH}$ 8) of MRSB on BLIS production by E. faecalis K2B1 
Table 1. Protein concentration produced by E. faecalis K2B1

\begin{tabular}{llcccc}
\hline \multirow{2}{*}{ Sample } & \multirow{2}{*}{ Volume $(\mathbf{m L})$} & \multirow{2}{*}{ Protein concentration $(\boldsymbol{\mu g} \mathbf{g} \mathbf{m L})$} & \multicolumn{3}{c}{ Arbitary Unit $(\mathbf{m m} \mathbf{m} / \mathbf{m L})$} \\
\cline { 3 - 6 } & & & S. aureus & B. cereus & P. aeruginosa \\
\hline CFS & 490 & 111.8 & 60 & 196.7 & 126.7 \\
Precipitate & 15 & 161.9 & 70 & 259.3 & 262.7 \\
Crude enterocin & 18 & 9.27 & 25.3 & 336 & 259.3 \\
\hline
\end{tabular}

Initial characterization of BLIS produced by E. faecalis K2B1 was tested against $S$. aureus activities after treatment at various temperatures, $\mathrm{pH}$ and also addition of Proteinase-K. In this study, BLIS was observed active at high temperatures and $\mathrm{pH}$, at $100{ }^{\circ} \mathrm{C}$ and $\mathrm{pH} 10$, but antimicrobial activity was disappeared after treatment with proteinase-K enzyme (Figure 3 ). Protease-K may destruct the structure of bacteriocin and vanishing its activity.

\section{Partial purification and characterization of crude enterocin}

The results of partial purification optimization revealed that the most optimum crude enterocin production has occurred at the addition of $80 \%$ ammonium sulfate concentration. This can be seen from the protein concentration produced (Figure 4). The results of antimicrobial activity tests of crude enterocin on pathogens $S$. aureus, $P$. aeruginosa and $B$. cereus can be seen in table 1. Protein concentration of precipitated bacteriocin was higher than BLIS and crude enterocin (Table 1).

Characterization was carried out by treatment of crude enterocin with proteinase-K (1: 1) and control using disk antibiotic. The results showed that the antimicrobial activity of crude enterocin was disappeared after treatment with Proteinase-K. (Figure 5 and 6).

The next characterization was the determination of molecular weight of crude Enterocin E. faecalis K2B1 using SDS-PAGE (Figure 7).

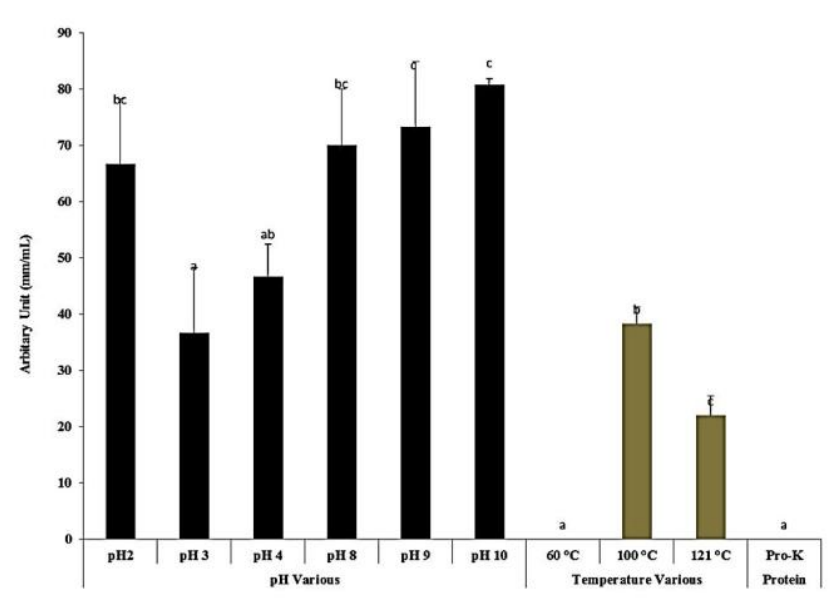

Figure 3. Antimicrobial Activity of Neutral CFS (BLIS) against S. aureus

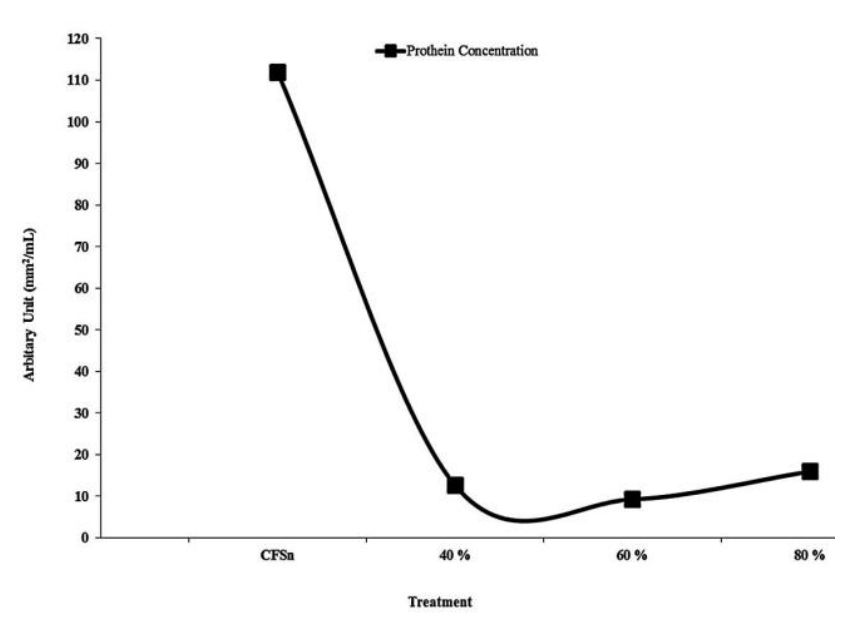

Figure 4. Concentration and activity of crude enterocin to Staphylococcus aureus

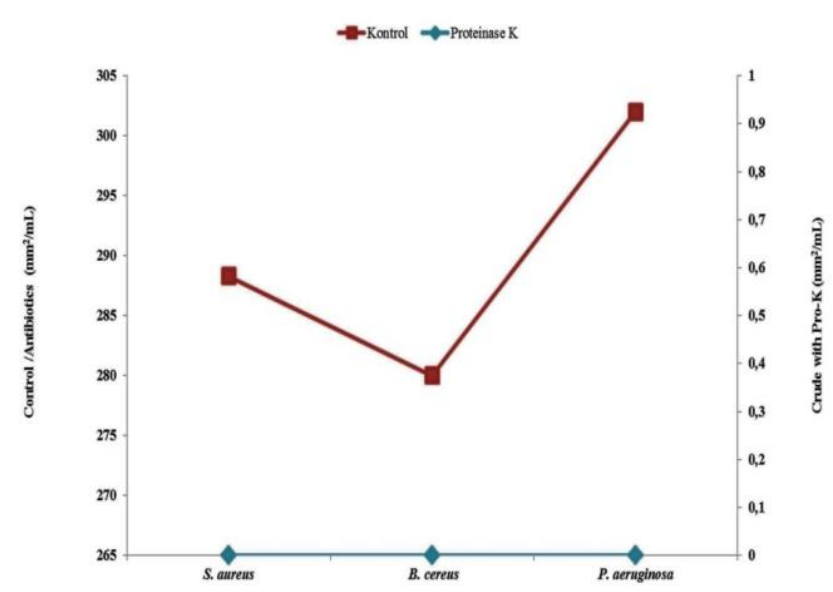

Figure 5. The effects of crude enterocin after being treated by proteinase K against $S$. aureus, B. cereus, and P. aeruginosa 


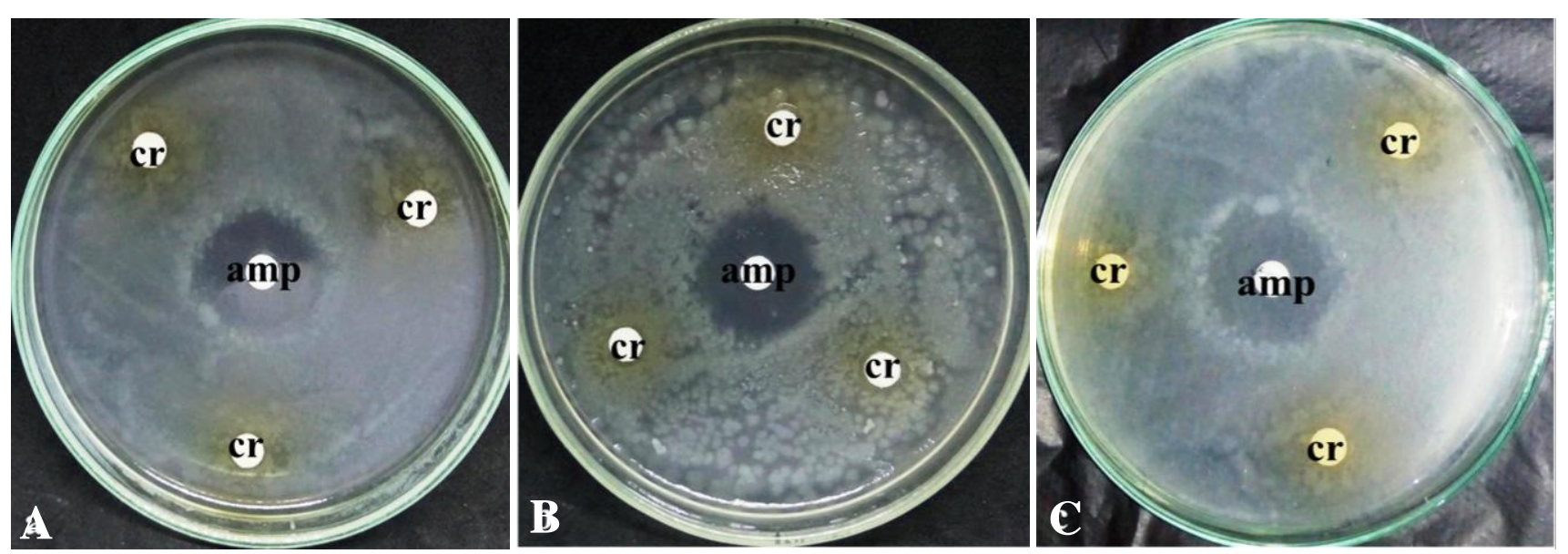

Figure 6. Antimicrobial activity of crude enterocin after treated by Proteinase-K. A. B.cereus, B. P.aeruginosa and C. S. aureus, (cr: crude enterocin, amp: ampicillin)

\section{Discussion}

In this study, we performed optimization and characterization of enterocin from E. faecalis K2B1, which was first isolated from Toraja's Belang Buffalo milk. Optimization was using two variables, incubation periods and different initial $\mathrm{pH}$ of MRS broth. The result showed that maximum BLIS production from E. faecalis K2B1 was on MRS broth with initial $\mathrm{pH} 8,13^{\text {th }}$ hours of growth, at the late exponential phase and decreased after the exponential phase (Figure 2.C). Similar results have been reported in studies with other LAB. BLIS from E. faecium B3L3 (Yusuf and Hamid 2012), Lactobacillus crustorum MN047 (Yi et al. 2016), Enterococcus faecalis KT11 (Abanoz and Kunduhoglu 2018), E. faecium AUO2 (Bello et al. 2018), Pediococcus acidilactic kp10 (Sidek et al. 2018) and P. acidilactic (Tankoano et al. 2019), that optimum production of bacteriocin was at the late exponential phase or initial stationery phase at 6 th, $24^{\text {th }}, 18^{\text {th }}, 21^{\text {th }}, 20^{\text {th }}, 9^{\text {th }}$ hours after fermentation, respectively. Bacteriocin is the primary metabolite product and generally begins to be produced at the late exponential phase until the stationary phase. The initial $\mathrm{pH}$ of growth medium plays an important role in the growth and bacteriocin production (Yusuf and Hamid 2012). The difference in expression of the enterocin gene is influenced by the type of strain producing, the growth phase, the $\mathrm{pH}$ of the media, the incubation temperature (Yusuf and Hamid 2012; Goh and Philip 2015; Avaiyarasi et al. 2016). The decrease of BLIS activity after exponential phase was probably because of the bacteria cell released proteolytic enzyme which is antagonistic against bacteriocin (Todorov and Dicks 2009; Yusuf and Hamid 2012).

Initial characterization was conducted by observing the antimicrobial activity of BLIS after treatment on various conditions e.g. heat treatment, wide $\mathrm{pH}$ range and proteinase $\mathrm{K}$ (Figure 3). Criteria for bacteriocin as bio preservative agent is stable at various storage conditions. In this study, we found that BLIS was stable at temperature of
100 dan $121^{\circ} \mathrm{C}$. Similar to our results, previous studies have been reported Enterocin from $E$. durans (Du et al. 2017), E. hirae (Gupta et al. 2016), E. faecalis (Khalkhali and Mojgani 2017; Xi et al. 2017), E. faecalis KT11 (Abanoz and Kunduhoglu 2018), its BLIS was heat-stable for $10-20 \mathrm{~min}$ at $121{ }^{\circ} \mathrm{C}$. This confirms that BLIS is possibly used as biopreservation for food because it is not denatured when sterilized using autoclave and applied as preservative. When exposed to range of $\mathrm{pH}$, it seems that BLIS E. faecalis K2B1 stable when exposed to acidic and alkaline. Similar to our finding, Enterocin from E. hirae LD3 (Gupta et al. 2016), E. durans 152 (Du et al. 2017), E. faecalis CV7 (Perumal and Vankatesen 2017), E. faecalis KT11 (Abanoz and Kunduhoglu 2018) were stable in the $\mathrm{pH}$ range 2-8, 2-6, 4-6, 2-11, respectively. This characteristic determines its usefulness in food system especially food manufacturing process. After treatment with proteinase K, BLIS was inactive. Our result was found consistent with Bello et al. (2018), who found that BLIS Enterococcus was stable at high temperature, acidic until alkaline $\mathrm{pH}$, and inactive after treatment with proteolytic enzymes. This is because of reason that bacteriocin is a protein that can be denatured by enzyme proteinase- $\mathrm{K}$ (Avaiyarasi et al. 2016). Nevertheless, stability to heat and various $\mathrm{pH}$ of enterocin from partial purified was not evaluated. Thus, it is interesting to conduct a comparative study on the stability between BLIS and partially purified enterocin to further characterize the compound prior to commercial applications.

Partial purification of enterocin was maximum by the addition of $80 \%$ ammonium sulfate based on its protein concentration value (Figure 4). These results are similar to Goh and Philip (2015). Antimicrobial activity of crude enterocin against pathogen has a broad spectrum because it is able to inhibit Gram-positive (S. aureus, and B. cereus) and Gram-negative ( $P$. aeruginosa) bacteria. The highest crude enterocin activity was against $B$. Cereus (Table 1). Our result similar to other studies conducted by Abanoz 
and Kunduhoglu (2018), who found that enterocin from $E$. faeclis KT11 can inhibit B. cereus, Tankoana et al. (2019), found that bacteriocin Pediococcus acidilactic can inhibit food-borne pathogen such as Bacillus. Characterization of crude enterocin by its activity after the addition of proteinase-K, and determination of molecular weight. The result showed that antibacterial activity of crude enterocin was completely disappeared after treatment with proteolytic, but ampicillin as a control in this research showed that its still able to inhibit growth of the three pathogen bacteria (Figures 5 and 6). Similar results were shown by Banwo et al. (2012), Udhayashree et al. (2012) and Yi et al. (2016).

The determination of molecular weight of Enterocin $E$. faecalis K2B1 was using SDS-PAGE, which was stained with coomassie brilliant blue. The stained SDS-PAGE results did not show protein bands (Figure 7). A very lower concentration of protein from precipitated bacteriocins to partially purified bacteriocins could be occurred due to the dialysis process. A similar thing was found by Ferreira et al. (2007), who did not obtain a band for SDS-PAGE staining. This might be due to the lack of concentrated protein or its concentration was too small.

The unstained gel SDS-PAGE was used for a direct examination of antimicrobial activity using agar overlaid method, for the presence of an inhibitory zone. The inhibition zones were observed from the gel containing crude enterocin for determination of enterocin MW (Pingitore et al. 2007; Abanoz and Kunduhoglu 2018). SDS-PAGE gel without staining was washed with sterile aquadest so the remaining SDS can be cleaned. This was carried out to avoid the zone of inhibition due to the influence of detergents. Based on the SDS-PAGE overlaid, it can be concluded that the peptide responsible for antimicrobial activity, has a molecular size of ranging from 5-10 kDa (Figure 7).

Our result was similar to the other studies obtained from some Enterococcus strains. E. feacium GM1 (Sarra et al. 2013), E. durans (Du et al. 2017), E. faecalis CV7 (Perumal and Venkatasen 2017), and E. faecalis KT11 (Abanoz and kunduhoglu 2018) have 4,5 kDa, $5 \mathrm{kDa}$, $4,829 \mathrm{kDa}$ and $3,5 \mathrm{kDa}$, respectively. From this result, it can be concluded that enterocin E. faecalis K2B1 from Toraja's Belang Buffalo Milk Makassar, Indonesia presumably could produce non-lantibiotic class II bacteriocin due to its MW ranging 5-10 kDa. Class II nonlantibiotic bacteriocin with heat-stable, small peptide with a low molecular weight ( $<10 \mathrm{kDa})$. Some studies mentioned that enterocin has a small MW, which ranges from $2.5 \mathrm{kDa}$ to $10 \mathrm{kDa}$ (Yusuf and Hamid 2012; Sarra et al. 2013; Avaiyarasi et al. 2016).

In conclusion, the optimum production conditions of Enterocin Enterococcus faecalis $\mathrm{K} 2 \mathrm{~B} 1$ isolate from Toraja's Belang buffalo milk were at MRSB $\mathrm{pH} 8,13^{\text {th }} \mathrm{h}$ after fermentation, and addition of $80 \%$ ammonium sulfate. Crude Enterocin had a broad spectrum, was sensitive to Proteinase-K and had 5 kDa MW.

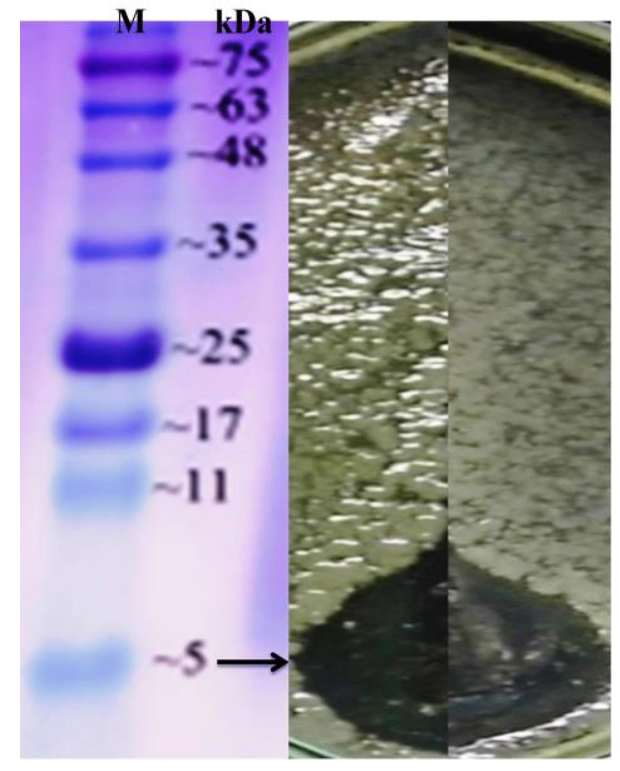

Figure 7. Determination of molecular weight of the crude enterocin by SDS-PAGE with prestained protein marker 5-245 $\mathrm{kDa}$. The enlargement of inhibition zones showed by arrows indicates the location of presumptive protein bands

\section{REFERENCES}

Abanoz HS, Kunduhoglu B. 2018. Antimicrobial activity of a bacteriocin produced by Enterococcus faecalis KT11 against some pathogens and antibiotic-resistant bacteria. Korean J Food Sci An 38 (5): 1064-1079.

Alang H, Kusnadi J, Ardyati T, Suharjono. 2019. Identification of lactic acid bacteria as a probiotic candidate isolated from the fresh milk of Toraja Belang Buffalo, South Sulawesi, Indonesia. Drug Invention Today 11 (3): 539-547.

Araujo TF, Ferreira CDLF. 2013. The Genus Enterococcus as probiotic: safety concerns. Braz Arch Biol Technol 56 (3): 457-466.

Arquest JL, Rodriquez E, Langa S, Landete JM, Medina M. 2015. Antimicrobial activity of lactic acid bacteria in dairy products and gut: effect on pathogens. Biom Res Int 1-9.

Avaiyarasi ND, Ravindran AD, Venkatesh P. 2016. In vitro selection, characterization and cytotoxic effect of bacteriocin of Lactobacillus sakei GM3 isolated from goat milk. Food Control 69: 124-133.

Banwo KA, Sann, Tan H. 2012. Technological properties and probiotic potential of Enterococcus faecum strain isolated from cow milk. J Appl Microbiol 114: 229-241.

Bello OO, Olubukola OB, Mobolaji A, Muibat OF, Temitope KB. 2018. Partial purification and application of bacteriocin from bacteria isolated Parkia biglobosa seeds. NE Sci 3(2): 72-94

Braiek OB, Ghomrassi H, Cremonesi P, Morandi S, Fleury Y, LeChevalier P, Hani K, Bel Hadj O, Ghrairi T. 2017. Isolation and characterization of an enterocin P-producing Enterococcus lactis strain from a fresh shrimp (Penaeus vannamei). Antonie van Leewenhoek 110: 771-786.

Du L, Liu F, Zhao P, Zhao T, Doyle MP. 2017. Characterization of Enterococcus durans 152 bacteriocins and their inhibition of Listeria monocytogenes in ham. Food Microbiol 68: 97-103.

Ferreira AE, Canal N, Morales D, Fuentefria DB, Corcao G. 2007. Characterization of enterocins produced by Enterococcus mundtii isolated from human feces. Braz Arch Biol Technol 50 (2): 249-258.

Goh HF, Philip K. 2015. Purification and characterization of bacteriocin produced by Weissella confuse A3 of dairy origin. PLoS ONE 1-17. DOI: 10.1371/journal.pone.0140434.

Gupta A, Tiwari SK, Netrebov V, Chikindas ML. 2016. Biochemical properties and mechanism of action of enterocin LD3 purified from Enterococcus hirae LD3. Probiotics Antimicrob Proteins 8: 161-169. 
Khalkhali S, Mojgani N. 2017. Bacteriocinogenic potential and virulence traits of Enterococcus faecium and E. faecalis isolated from human milk. Iran J Microbiol 9: 224-233.

Leite JA, Fabricio LT, Fernanda BRT, Leon R, Jeane QC, Nathalia GR, Hamilton C, Elaine CPM. 2016. Bacteriocin-Like Inhibitory Substance (BLIS) produced by Bacillus cereus: Preliminary characterization and application of partially purified extract containing BLIS for inhibiting Listeria monocytogenes in pineapple pulp. Food Sci Technol 27: 261-299.

Ogaki MB, Rocha KR, Terra MR, Furlaneto MC, Maia LF. 2016 Screening of the enterocin-encoding genes and antimicrobial activity in Enterococcus species. J Microbiol Biotechnol 26 (6): 1026-1034.

Perumal V, Venkatesan A. 2017. Antimicrobial, cytotoxic effect and purification of bacteriocin from vancomycin susceptible Enterococcus faecalis and its safety evaluation for probiotization. LWT-Food Sci Technol 78: 303-310.

Pingitore EV, Salvucci E, Sesma F, Nader-Macias ME. 2007. Different strategies for purification of antimicrobial peptides from Lactic Acid Bacteria (LAB). In: Mendez-Vilas A (eds.). Communicating Curren Research and Educational Topics and Trends in Applied Microbiology. Formatex, Spain.

Sarra M, Taoufik G, Patrick LC, Benjamin B, Yannick F, Khaled H. 2013. Isolation and characterization of Enterococci bacteriocins strains from Tunish Fish Viscera. Food Nutr Sci 4: 701-708.

Sidek NLMd, Murni H, Joo ST, Sahar A, Shuhaimi M, Arbakariya BB 2018. Stability of Bacteriocin-Like Inhibitory Substance (BLIS) produced by Pediococcus acidilactici kp10 at different extreme conditions. Biomed Res Int. 2018: 5973484. DOI: 10.1155/2018/5973484

Tankoano A, Michel BD, Hagretou SL, Malick M, Donatien K, Yves T, Aly S. 2019. Isolation and characterization of lactic acid bacteria producing Bacteriocin Like Inhibitory Substance (BLIS) from 'Gappal', a dairy product from Burkina Faso. Adv Microbiol 9: 343358.

Thirumurugan A, Ramachandran S, Gobikrishnan S. 2015. Optimization of medium components for maximizing the bacteriocin production by Lactobacillus plantarum Atm 11 using statistical design. Intl Food Res J 22 (3): 1272-1279.

Todorov SD, Dicks LM. 2009. Bacteriocin production by Pediococcus pentosaceus isolated from marula (Scerocarya birrea). Intl J Food Microbiol 132 (2-3): 117-126.

Udhayashree N, Senbagam D, Senthilkumar B. 2012. Production of bacteriocin and their application in food products. Asian Pac Trop Biomed 2 (1): S406-S410.

Xi Q, Wang J, Du R, Zhao F, Han Y, Zhou Z. 2017. Purification and characterization of bacteriocin produced by a strain of Enterococcus faecalis TG2. Appl Biochem Biotechnol 184: 1106-1119.

Yi L, Ying D, Jingli W, Lihui Z, Xiaojiao L, Bianfag L, Yuan Z, Xin L. 2016. Purification and characterization of a novel bacteriocin produced by Lactobacillus crustorum MN047 isolated from koumis from Xinjiang, China. J Dairy Sci 99: 7002-7015.

Yusuf MA, and Hamid THATA. 2012. Optimization of temperature and ph for the growth and bacteriocin production of Enterococcus faecium B3L3. IOSR J Pharm 2 (6): 49-59. 